Meta

Journal des traducteurs

Translators' Journal

\title{
How I Came to Be a Translator
}

\section{Robin Inches}

Volume 38, numéro 4, décembre 1993

Le Je du traducteur

The $I$ of the Translator

URI : https://id.erudit.org/iderudit/003166ar

DOI : https://doi.org/10.7202/003166ar

Aller au sommaire du numéro

Éditeur(s)

Les Presses de l'Université de Montréal

ISSN

0026-0452 (imprimé)

Découvrir la revue

Citer cette note

Inches, R. (1993). How I Came to Be a Translator. Meta, 38(4), 734-735.

https://doi.org/10.7202/003166ar

\section{Résumé de l'article}

Après une carrière dans l'armée, où il a été interprète officiel, l'auteur est maintenant traducteur. Il relate les faits marquants de sa vie professionnelle.
Ce document est protégé par la loi sur le droit d'auteur. L'utilisation des services d'Érudit (y compris la reproduction) est assujettie à sa politique d'utilisation que vous pouvez consulter en ligne.

https://apropos.erudit.org/fr/usagers/politique-dutilisation/ 


\section{HOW I CAME TO BE A TRANSLATOR}

Résumé

Après une carrière dans l'armée, où il a été interprète officiel, l'auteur est maintenant traducteur. Il relate les faits marquants de sa vie professionnelle.

Born in the italian part of Switzerland to a German-born mother and a Scottish father, I really had three languages in the mother-fongue category: German, English and Italian. German predominated, because that was the only language our maids(!) spoke, but I made my first foray into interpreting (when I was about eight) working between English visitors to a lake (-Lugano)-side tea-garden and the staff there who spoke only Italian. My initial schooleducation was split between Germany (Freiburg) in winter and the village school (mornings only) in summer - a regime I can thoroughly recommend. When things became more serious I was sent to an international boarding school in Baden-Baden, where a splendid native-French teacher and French-speaking friends of my parents introduced me to, and made me love, that language. (I still know by heart Le corbeau et le renard which I learnt then). Just as that school was starting me on English as the second foreign language - useful, because it taught me grammar - my father decided I really had to have some Scottish education to fit me for a job in the UK, and I was moved to a boarding school in Edinburgh. There they carried on teaching me French - badly, mind you - and I was given time for my German. My Italian I used to help with the to me knew but compulsory Latin, though my ability to produce slick translations while showing neither ability nor application on the grammar side - to him much more important - drove my teacher to fury.

On leaving school I joined the Engineering branch of the Navy in January 1940. After nearly four years' training, to degree level, I was sent to a battlecruiser, which promptly sailed for the East Indies. There my languages were of little use, but fifteen months later in April 1945 my ship was recalled to home waters and became the venue for the German Scandinavian Command surrender negotiations. As there was no time to send interpreters up from London and I was the only German-speaker on board, I had a lively 48 hours. That automn I was sent to the naval college at Greenwich for two years' post-graduate training. The university-type summer breaks during this period allowed me to visit my native village again; the time there and the journey through France and Germany knocked the rust off my various languages - though whether the attention mines! along the road edges in France was in French or in English I never did find out. Another sea appointmemt followed but was cut short in July 1948 when, the authorities having become aware of my German, I was sent to Germany where the Russian had suddenly started repatriating prisoners of war in large batches in an attempt to swamp Allied Intelligence. My job was to debrief those who had worked in shipyards or similar installations, which had suddenly become important because the Russian navy had started to expand in a big way, and about which we knew very little. After 18 months of that I had little trouble in getting a first class pass in the Civil Service Interpreters' Exam (CSIE) - then and for a long time after the qualifying hurdle for interpretership in all three Services. That made me officially an interpreter! Back in a shore appointment in UK again, my French and German were kept alive by technical liaison visits. As I didn't want to lose my Italian and evening classes in that language were on offer in Portsmouth, near where we lived, I went to these. My teacher there - a native-Italian lady — was pleased enough with me to suggest I should go on to the University for foreigners at Perugia. I didn't see much chance of that but then suddenly in summer 1957 the navy admitted that for six months they really didn't know what to do with me. I proposed Perugia and to my amazement was granted not only three months (one course length) there but also a further three at the naval academy in Livorno, officially to update the E-I-E naval dictionary. A CSIE first class pass in Italian was then not difficult, and a year in a destroyer in the Med. gave the navy a return for its investment. Though I never got another useful posting abroad (two years in Turkey saw me starting on Turkish, but I was thoroughly put off by finding that in essence it was totally different from all my other languages), NATO conferences, more technical liaison work, plus holidays abroad stopped me getting rusty. So when I was retired from active service in December 1985 I was near bilingual in German and pretty fluent in the other two languages.

What to do now - at only 55 I couldn't just stop working altogether! Having my retired pay meant that I was not compelled to take a full-time job to make a living, so I was able to consider doing part-time something that I enjoyed. Interpreting - which was what the Navy predominantly required from me - I had found both interesting and enjoyable while it was part of my active service, but now would mean travelling to wherever the work was, whenever I was wanted. Not really what $I$ had in mind. By a stroke of luck, Alan Braley, who was then running $A B L E$ TRANSLATIONS near where I was living, just then advertised for a translator. I followed this up, and though he 
actually wanted someone to join his staff he was kind enough to point me in the direction of free-lance translating and gave me a lot of valuable starting advice.

After a spell of general work, I concentrated on translating and abstracting: extracting the essence from a text of unspecified length (a patent application) in German and expressing it in not more than 100 words in English. Technically most interesting: in the forefront of technology, and wide-ranging; my field extended from straw-burning furnaces through sailbords and their fitting to space stations, I did this for several years until I decided that for the effort I was putting in I was really getting a very poor financial reward. So back to general work again, which I am still doing. However a couple of years ago, in a manner which I can't precisely recollect, I established a link with a publisher of books on nautical matters setting up an office in the nearest town. Translating books / booklets/pamphlets from German for this firm has become my main activity - paid at the going rate and a lot more relaxed as regards timing than what I had been accustomed to.

Now rising 70, where do I stand? I am still enjoying translating enormously. I suspect I am getting more and more out of date as regards information technology, but with the old-fashioned means at my disposal, plus of course the help I can get from other ITI members, I am still coping quite happily. So I shall carry on until there is some major change in one of those two respects - or until I don't get any work anymore!

ROBIN INCHES

United Kingdom 